\title{
I Want a Poem ${ }^{1}$
}

\section{Shukria Rezaei ${ }^{2}$ \\ Afghanistan/United Kingdom}

[Article copies available for a fee from The Transformative Studies Institute. E-mail address: journal@transformativestudies.org Website: http://www.transformativestudies.org (02020 by The Transformative Studies Institute. All rights reserved.]

I want a poem

with the texture of a colander

on the pastry.

A verse

of pastry so rich

it leaves gleam on your fingertips.

\section{A poem}

that stings like the splash of boiling oil

as you drop the pastry in.

\section{A poem}

that sits on a silver plate with

nuts and chocolates, served up to guests who

sit cross legged on the thoshak.

\section{A poem}

as vibrant as our saffron tea

served up at Eid.

\footnotetext{
${ }^{1}$ Printed with permission.

${ }^{2}$ Shukria Rezaei, a published and prize-winning poet, left her home Afghanistan to escape the ongoing attacks on the Hazara people by the Taliban. Following refuge in Pakistan, she and her mother moved on to Oxford to be reunited with her father. She won her first poetry prize at the age of fifteen, less than a year after her arrival in England. She now attends the University of London.
}

1937-0229 C2020 Transformative Studies Institute 
Let your poetry

texture the blank paper

like a prism splitting light

Don't leave without seeing all the colours. 